\section{CNRS plans 'modernization'}

Parls

ThE Centre National de la Recherche Scientifique (CNRS), the principal state organization for basic research, last week published its plans for 'modernization', in line with a government directive in October 1988 . The theme, as presented by director-general Francois Kourilsky, is 'better management'.

Although couched in encouraging language, the three-year 'strategic plan' seems destined to create casualties. But researchers will have to wait until February 1990 before the plans are finalized.

CNRS researchers will find some solace in the proposals. There will be no attempt to transform the CNRS into a research council "funding universities in crisis" along "Anglo-Saxon" lines. "This hypothesis has been abandoned", says Kourilsky. "We fully adopt the French model of the CNRS as a research organization." Kourilsky was obliquely referring to the previous government's plans to dismantle the CNRS in order to end the schism between universities, grandes écoles (academies) and research laboratories.

The major buzz-words of the new plan are: "decompartmentalization", "clear scientific strategies", "solidarity around major interdisciplinary projects", "mobilization of manpower", "competitivity" and "partnership". A new programme directorate will be created to ensure that the three-year plan is respected, while boundaries between disciplines will be redefined. "Vast" interdisciplinary projects are being formulated, such as research on the environment, new materials, macromolecules and communications science.

The manner in which the CNRS and its laboratories are run is Kourilsky's most immediate preoccupation. Several 'working groups' have been set up to redefine both central and laboratory management along with a permanent system of internal audits. There is to be a "significant adaptation" of CNRS Paris headquarters, while the new plans include more conspicuous regional administrative delegations. A new secretary-general, Jean-Marie Bertrand, has been appointed to coordinate these administrative initiatives. A document sent to researchers, entitled "The development of human resources", suggests that laboratories should be seen as "small or medium enterprises" and their directors given management training. Priority is given to a reevaluation of the post of researcher.

At present, different proposals are being considered, including the introduction of fixed-term contracts and permanent facilities for specialized training. But a commitment to "favour the recruitment of young researchers" could run into difficulties. The starting salary is set at about FF102,000 $(\$ 16,000)$ per year, while the average age of a recent postdoc is 27 years. Salaries offered by industry are almost twice as high.

The sting in Kourilsky's message is hidden behind the heading: "assuring the competitivity of laboratories". Laboratory running costs have not kept pace with the need for expensive equipment and computers, he says. As a result, some laboratories are "on the verge of losing the means to carry out competitive research on an international level". But, since "the creation of new laboratories will become strictly dependent on budgetary means", criteria of excellence will be "more rigorous" as from this year.

Research units whose "activity has declined" will not see their grants renewed. This, says Kourilsky, is "normal CNRS procedure". Between 1986 and 1988, CNRS withdrew from 120 research units. Current options mean that "this tendency will unavoidably be increased". As a result, some researchers whose grants have been cut will continue to receive only their salaries for a maximum of two years pending their integration within more efficient groups. This will be of no comfort to researchers in life sciences who had hoped they could appeal against cuts

\section{Washington}

A LONG campaign by US high-energy physicists took what may be its penultimate step last week, with the decision by the House of Representatives to approve $\$ 110$ million to begin building the Superconducting Super Collider (SSC). Another \$90 million is authorized for continued research and development on the 16-mileacross, $20-\mathrm{TeV}$ proton accelerator. The sum is $\$ 50$ million less than the Department of Energy (DoE) had requested, but the budget item still needs Senate approval, and DoE officials will push to get the whole request included in the final US budget.

Money for SSC construction has been put into the president's budget for the past three years, but on the previous two attempts had not survived passage through Congress. A factor in this year's success was apparently a letter written by Energy Secretary James Watkins to Representative Tom Bevill (Democrat, Alabama), chairman of the Appropriations subcommittee on energy and water development, assuring him that a contribution of $\$ 500$ to $\$ 1,000$ million, in cash or in kind, towards the SSC would be forthcoming from Japan. DoE officials have expressed confidence all being made by their departmental director (see Nature 339, 326; 1 June 1989). Of prime concern to researchers, but absent from Kourilsky's presentation, is the reassurance that cuts will be based upon the advice of peer committees.

Faced with the need for "creative accounting', CNRS will impose a moratorium on new projects involving very large instruments until 1991. CNRS at present spends FF560 million of its annual FF9,700-million budget on very large instruments, such as telescopes, at the expense of laboratory running costs. "We have seen the cancellation of approved research in order to protect international projects", said Kourilsky.

Finally, CNRS will be encouraged to reinforce partnerships with universities, with industry and with other European research institutes. The potential for greater complementarity between CNRS research opportunities and university teaching will be exploited through common researcher training programmes and joint laboratories.

At the same time, a new agreement has been signed with ANVAR, the national agency for technology transfer. To facilitate European collaboration, all the French state research organizations will be represented in Brussels through a new agency, CORA (club of assimilated research organizations).

Peter Coles

\title{
SSC is brought another step nearer reality
}

along that foreign and non-federal contributions would decrease the burden on the US taxpayer, but so far the only formal promise is for $\$ 50$ million in kind from India.

While most foreign governments balked at promising support before a decision to build the SSC was made, many congressmen wanted to see firm evidence of foreign interest before they would vote for construction money. The letter from Watkins to Bevill, based on an informal feeling for the possible extent of Japanese help, may have helped to break the stalemate, but may also jeopardize future negotiations not only with the Japanese, who have made no official commitment to cost-sharing, but also with other potential contributors, who could decide their help is no longer needed.

DoE is working on plans to set about securing foreign assistance, and clarifying what participants could expect in return, but Japanese officials are thought to be nervous at the prospect of being invited to contribute the amount suggested. Despite much talk, at least in the United States, Japan has given no outward sign of interest in helping with SSC, but would be uncomfortable at having to say no. David Lindley 